\title{
THE POTENTIALS AND THE TENDENCIES OF THE ECONOMIC DEVELOPMENT OF KLOS MUNICIPALITY
}

DOI: http://dx.doi.org/10.18509/GBP.2019.44

UDC: 332.1:911.373(496.5)

\author{
Fatjon Bebja \\ Sonila Papathimiu \\ University of Tirana, Faculty of History and Philology, \\ Department of Geography, Albania
}

\begin{abstract}
Sustainable development is a priority of every strategic plan and of national and local policies which aim to achieve economic growth. In this context the municipality of Klos should make a complex analyze and inventory of all its natural, human and economic potentials as well of all the investments made till now and others which are planned for the future.

Municipality of Klos is a new one, formed after the last Administrative and Territorial reform of Albania in 2015 and includes four administrative units: Klos; Gurrë; Suç and Xibër. Klos is a municipality which has in its administration 30 villages spread in an area of $357.5 \mathrm{~km}^{2}$, while the town of Klos is the main urban area with a surface of $114 \mathrm{~km}^{2}$. The relief of the town of Klos is mainly hilly and mountainous which sometimes are positive and supportive to the economic development and in other cases hamper it. This complex impact of the relief and other resources of the area should be treated carefully and taken in consideration by future policies and strategic plans.

This paper aims to analyze most of the natural, human and economic potentials of the Municipality of Klos, focusing on its current economic development and the tendencies for the future.

The main methodologies used in this paper are: collecting and analyzing data on infrastructure from different institutions for many years; field interviews and surveys; statistical data analyze and comparison, mapping etc. The results and recommendation from this paper can serve the local government to use better its resources and to have better economic development.
\end{abstract}

Keywords:natural, human, sustainable development, sustainable tourism.

\section{INTRODUCTION}

This paper aims to analyze and evaluate the potentials and tendencies of the economic development of Klos municipality. This municipality is mostly hilly-mountainous and is part of Mati region. Klos municipality has many specific problems which sometimes act as promoter and other times as an obstacle for the economic development and that should be taken in account by the future policies and strategic plans. The priorities of the municipality are the right use of natural and human resources and sustainable development of agriculture and livestock as well as promotion of rural tourism. Klos municipality has been inhabited from ancient time which is testified by the archaeological findings in the area and the castles of Dars and Xibrit dating back to the $4^{\text {th }}$ century BC. The main economic activity in Klos has always been agriculture, where farming and livestock have been very important and the other economic branches have had less 
importance. The political, economic and social changes in Albanian after the decline of communism in 1990 affected also the economic structure of this municipality where other economic activities began to have more importance. Although these minor changes the municipality has a long tradition in agriculture and livestock and these two activities are still very important, but the population and local government are working to offer also touristic services. Tourism is becoming a very important sector in the Albanian economy and the central and local governments are emphasizing its role in the national incomes. The tourism sector in Albania has improved and adapted according the foreigners requests. The quality and variety of food offered in the hotels and restaurants has improved after the 1990 and very successful in this period are the areas which promote the traditional gastronomy of Albania. Many foreigners coming from the Western countries like the Albanian food and the way of serving [11]. Klos has many natural and human potentials to promote and invest in tourism and be successful as well.

\section{NATURAL OFFER OF KLOS MUNICIPALITY}

Klos Municipality is located in the northeast of Albania and is one of four municipalities of Dibra District (Dibra, Mat, Klos and Bulqiza). Klos is declared Municipality in the last Administrative-Territorial Reform in 2015, it has a surface of $357.5 \mathrm{~km}^{2}$ and has 4 administrative units: Klos, Gurrë, Suç and Xibër with almost 30 villages in it. Klosi town along Mati River valley is the center of Klos municipality (Fig 1).

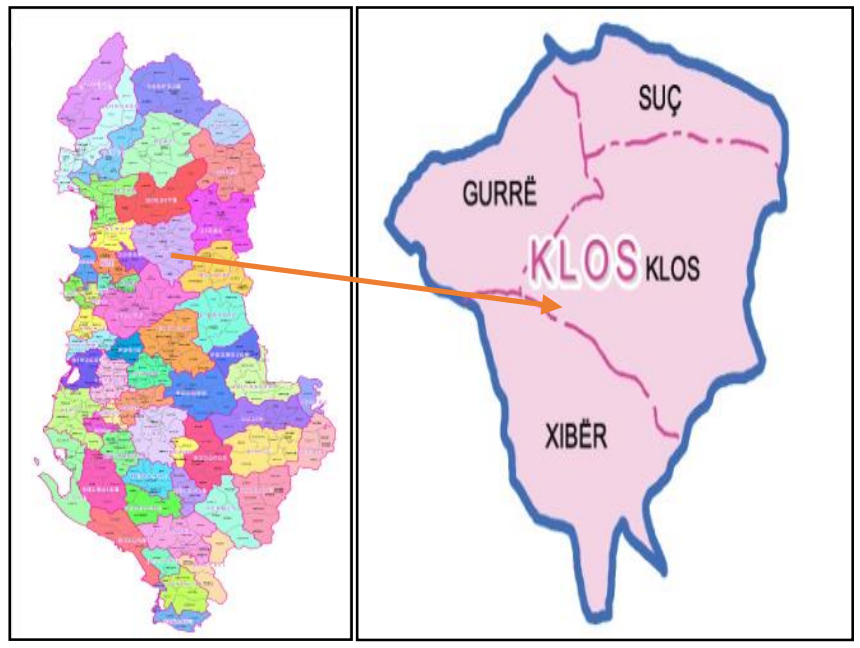

Figure 12. Location map of the studied area

Natural conditions of Klos municipality are very favorable for the development of human activities and especially for the economic sectors of agriculture, livestock and tourism. It also have rich chromium deposits which are associated with the magmatic rocks found in the area and are very important for the national and local economy. The relief of Klos municipality is mostly hilly and mountainous, but the valleys and small fields are not missing, offering variety for the tourists as well for the cultivation of different crops and for the raising of free range livestock. Climate is another natural element which is very favorable for the development of the economic activities in this municipality.[3] Most of the year the temperatures are mild to hot in summer. January is usually the coldest month with temperatures falling to $-5^{\circ} \mathrm{C}$ till $-10^{\circ} \mathrm{C}$ which cause frosting and have negative impact on the agricultural crops. In the frost periods the farmers should invest to save their cropping as well the livestock. Snow is present in the area, but it does not last more than 
3-4 days/year. These conditions make it possible the cultivation and growth of some traditional agricultural crops such as grain, forage, vegetables, etc.[14].Climate and the rich hydrographic network in the area have been crucial factors in the developing of agriculture and livestock in Klos. The main flow is Mati River which covers most of the villages in the Klos and is used to water the agricultural lands. Problems emerge during summer when due to the low precipitation the river flow dries and there is no water for the agriculture. Agriculture and livestock farming in the area are also favored by the variety of lands and their fertility. Rich vegetation provides whole year pastures for livestock. The area has very good conditions for the cultivation and production of nuts which are highly demanded in international and national markets and have a relatively high price. The main variety of nuts grown in the area are: nuts, hazelnuts, chestnuts, etc. [2]

\section{CHANGES IN THE POPULATION OF KLOS MUNICIPALITY}

\section{Population of Klos before 1990}

Klos area has historically served as a crossroad between some important areas of the country connecting Dibra with Tirana, Durresi, Kruja and Mirdita. The presence of stone medieval bridges in the area are a testimony of this important role of Klos municipality. The population of Klos, according to the first census in 1923 [12] was 6010 inhabitants with 879 families, although some villages were missing in that census. In the period 19451990 in Klos area the population as in the whole Albanian territory increased due to many factors: the pronatalist policies of the state; prohibition of the free movement of people; improvement of living conditions; reduction of the infant mortality rate etc.[4]

\section{Population of Klos after 1990}

After the 1990s, the change of political system from communist to democratic opening the possibilities for the free trade economy. In the new democratic system people were free to choose where to live and work and many of them moved to the main cities of the country and a larger number emigrated in the border countries, especially Italy and Greece. This movement of people happened also in the municipality of Klos and the population decreased in number. According to the last census of 2011 the population of Klos municipality was 15,336 inhabitants [1]. Most of its population is rural and the largest urban area is Klos town with 2,300 inhabitants or $15 \%$ of the total population [13]. (Table 1)

Table 8. Population change in Klos municipality, 2001-2011 [13]

\begin{tabular}{|l|l|l|l|l|l|l|}
\hline \multirow{2}{*}{$\begin{array}{l}\text { Administrative } \\
\text { Unit }\end{array}$} & Population & \multicolumn{2}{|l|}{ Age groups } & \multicolumn{2}{|l|}{} \\
\cline { 3 - 5 } & & $\begin{array}{l}0-14 \\
\text { (in \%) }\end{array}$ & $\begin{array}{l}15-64 \\
\text { (in \%) }\end{array}$ & $\begin{array}{l}>65 \\
\text { (in \%) }\end{array}$ & $\begin{array}{l}\text { Population } \\
\text { change } \\
2001-2011\end{array}$ & $\begin{array}{l}\text { Density } \\
\text { inhab./km } \\
2001-2011 \\
\%\end{array}$ \\
\hline Klos & 7873 & 23.2 & 65.9 & 10.91 & -24.94 & 54.57 \\
\hline Suç & 2716 & 23 & 65.32 & 11.63 & -24.74 & 43.4 \\
\hline Gurrë & 3369 & 26.9 & 63.43 & 9.68 & -22.96 & 47.8 \\
\hline Xibër & 2660 & 24.6 & 62.29 & 13.12 & -28.63 & 27.94 \\
\hline Albania & & $\mathbf{2 0 . 7}$ & $\mathbf{6 8}$ & $\mathbf{1 1 . 3}$ & -8.7 & 97.4 \\
\hline
\end{tabular}




\section{ECONOMIC DEVELOPMENT OF KLOS AND THE FUTURE TENDENCIES}

\section{Economic development of Klos before year 1990}

The main economic sector in Klos municipality has always been agriculture. Livestock has been more important and has played a major role in the economy of this municipality while the other economic sectors have not had any development in the area. Even before 1945 in the agricultural sector, livestock has been very important with higher production and earnings for the farmers than the other sectors of economy. In the period 1945-1990 in Klos municipality, as in the whole country, the agricultural cooperatives a communist organization were created and the land was again taken from the farmers to become state or cooperative's property. In Klos area were created three cooperatives: "Zonja Curre", "Bejnë-Klos" and "1-Maji".[5] The responsible for the economic and financial decisions of the cooperative was its chairman with other leaders usually chosen by the farmers, but approved by Labor Party. Klos had also a commercial enterprise, which was then called a consummator service co-operative, a small office of the Bank of Albania (the only operating Bank in the communist period) an office of civil status and registration of the population etc. Most of the population was employed in the agricultural sector which became very productive with high yields and cultivation of different cereals such as: corn; wheat; barley; oat; rye [7] etc.

In Klos municipality also were cultivated a large variety of vegetables: tomato, cucumber, pepper, eggplant, melon and watermelon. The lowlands in Klos municipality were cultivated with cereals and vegetables otherwise the hills were terraced and planted mostly with fruit trees. The climate and geographical position of Klos municipality are favorable and produce fruits of high quality, especially cherries, pears, plums, nuts and apples. The hills were also planted with black and white grape vineyards, which also was of very good quality.[8] The agricultural products were sold in Klos bazaar and in the larger urban area of Burrel. Most of the grape produced was used for the production of wine and raki- an alcoholic beverage typical of Albania similar to Russian vodka.In the winery of Klos the grape used was not only from the villages of this municipality, but also from the villages of Mat municipality.[6] Livestock as above mentioned was very successful during this period and had an incensement of castles and poultries. The milk produced was processed in a small milk production plant located in Klos, which supplied the local residents with dairy products. Part of the production was also sold in larger urban areas.[9]

\section{Economic development of Klos after year 1990}

The main changes in the economy of Klos after 1990 were in its sectorial structure, when other branches of economy began to attract more investments and importance. Although the efforts for big changes in the economy, the population is still traditionally agricultural. The main economic activities are still agriculture and livestock, but in difference with the period before 1990 now also services, especially tourism is getting more attention and investments. In Klos municipality agriculture has the highest number of the employees, around $80 \%$ and the main contributor to the municipality incomes. [10]There is a shift in the types of crops cultivated and more attention is given to the fruit trees which have very favorable conditions to grow in the area and are demanded in the market. The traditional agriculture products are competitive and in high quality.

After 1990, as in other administrative units of Albania, in Klos the small economy is struggling from the deterioration of infrastructure, poor investments, high prices and low 
quality of agricultural inputs etc. The small businesses opened in this municipality are in total 239, of which 196 in Klos town. Their number and variety has changed after 1990. The businesses operating in Klos municipality can be classified as follows [6]:

- 56\% services, small commercial units, transport and communications;

- $18 \%$ financial services and professional activities;

- $11 \%$ industrial businesses (mineral industry);

- $6 \%$ construction sector;

Although agriculture is very important in the area there are only $2 \%$ of businesses related to it.

The map on the distribution of economic activities in Klos shows that most of the local businesses are located along the National Road, Peshkopi-Tirana.

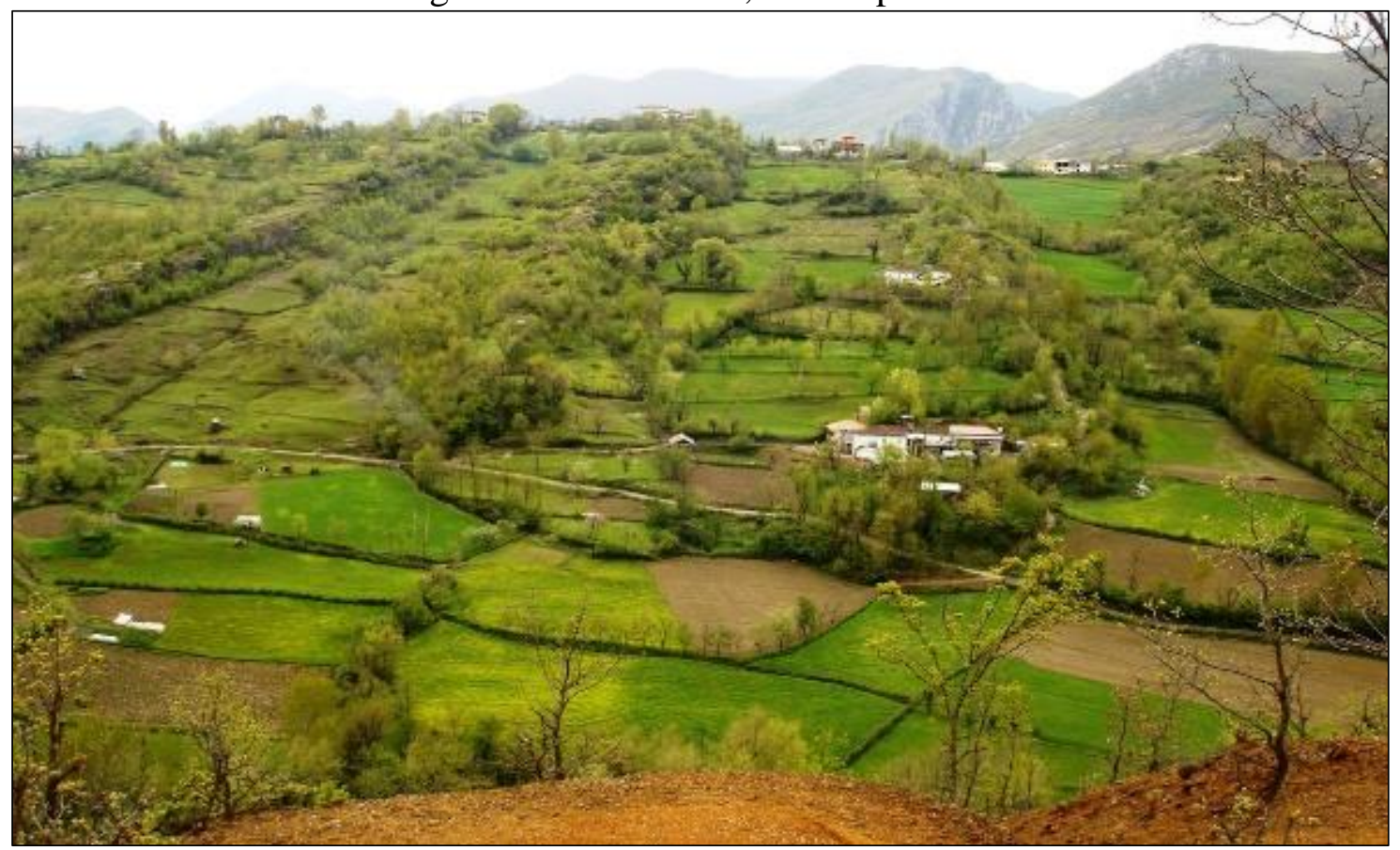

Picture 1. Village of Dars

On the other hand, as we can see on the map, most businesses are located along the TiranaPeshkopi National Segment [5].

\section{Future tendencies of economic development in Klos municipality}

The future economic development of Klos municipality will be defined by the ability of its people to use all its natural and human resources. The main economic sectors to be developed are agriculture (especially livestock), tourism and industry;

- Agricultureis a great potential for the area, with very fertile soils, tradition and mild climate. The small farms should collaborate more and create cooperatives to have the possibility to sell in the other regions and outside Albania.

- Tourism is another economic activity which is changing rapidly in Albania comparing with the communist period. Some areas which traditionally have not been touristic attractions are becoming and are having more tourists and tourism activities. Villages are using they attractive nature and culinary to become more attractive and to have more tourists. This tendency is seen also in Klos municipality and its villages. The area has many resources and potentials for the future development of rural tourism. In Klos municipality the tourists can visit many of its historical monuments, beautiful 
mountains, river valleys etc. Its vicinity with Tirana is another advantage for the development of Tourism.

- Industry have good opportunities to develop in Klos municipality which can use its vicinity with Bulqiza chromium mines and can invest in the processing industry and then transporting it to the Durres port. [12]

It is important for Klos municipality to design and implement strategic plans and projects for the future development and not be limited in small investments [6].

Some strategic objective where Klos municipality should focus and invest are:

Promote and encourage foreign and national investments in the area and in different branch of economy; Institutional investments and promotion of agro-industry for the agricultural and livestock products; Promoting of sustainable tourism (rural, culinary, nature, adventure and ecotourism). The Municipality should provide support through small grants to promote the local businesses and the employment of the young people, especially in areas with the greatest potential. Development of sustainable tourism will definitely help businesses and the local economy, so it is important that the municipality promotes its natural and cultural values.[10]

\section{RESULTS \& RECCOMENDATIONS}

- Municipality of Klos has a favorable geographic location that fully supports the development of multi-branch economy and easy and fast connection with the bordering municipalities of Bulqiza, Dibra, and Tirana.

- Its main natural resources which support future sustainable development are: rich climate, hydrologic network, hilly-mountainous relief combined with valleys and fields, fertile soils and high biodiversity.

- The economic structure of the municipality has undergone many changes after the decline of communism system in 1990 when other sectors of economy began to have more importance and investments, but still agriculture and livestock have the largest number of employees.

- Tourism has experienced a rapid development recently in the whole country. Klos municipality should work to attract more tourists and promote sustainable tourism.

Based on the results of the study some of the recommendations for the future development of Klos Municipality are:

- Klos Municipality will increase the economic benefits from its great natural, historical and cultural resources, only if designs and implements strategic plans in harmony with its ecosystems.

- Local and central government it is recommended to work closely for the designation and implantation of the best economic and social policies to reduce the emigration rate, especially of the young population.

- The farmers should be encouraged to create cooperativesto increase their yields and production and to compete in the regional and foreign markets.

- Local government it is recommended to give more attention and invest in the preservation and improvement of soil quality. Frequent training of the farmers for the principles of sustainable agriculture and livestock are necessary to improve the quality of the products.

- Tourism activity should be encouraged and the investments for this sector need to be directed to the preparation of human resources, publication of touristic maps, brochures, touristic guides etc. The businesses of the area should be encouraged as well to invest in tourism activity. 


\section{REFERENCES}

[1] Census, INSTAT, Albania 2011, pages 101-105

[2] Fiçorri R., "Mati and Mati people in history", Ilar,Tirana 2010, pages 3,11

[3]Fiçorri R., "Mati: a brief geographic, historic, economic and cultural study", Dardania, Tirana 1998, pages 4,10

[4] Fiçorri R., "My hometown Mati”Erik, Tirana 2008, pages 15-18

[5] Functional Area Burrel-Klos Program DLDP 2015, pages 9,12,16,21

[6]General Local Plan, Klos Municipality, Program DLDP 2017, pages 10,22

[7] Gjoka F., "Soils, their nature, characteristics and uses" Tirana 2007, pages 38-40

[8] Gjoka N., "Nature of Mat" publishing house Ilar, Tirana 2005, pages 24

[9] Journal "EMATHIA" publishing house Ilar, Tirana 2002, pages 19

[10] Kurti D., "Ethnographic Notes on Mat", Erik Tiranë 2004 pages 22

[11] Papathimiu, S. "The demographic and economic development of Albania during and after the decline of Communist regime (1945-2010)." Treballs de la Societat Catalana de Geografia [en línia], 2012, , p. 101-118.

https://www.raco.cat/index.php/TreballsSCGeografia/article/view/258331/345736

[12] Strategic Plan of Klos Municipality, Idra research\&Consulting, 2015, pages 48

[13] Office of Civil Status, Klos Municipality 2017

[14] Ymeri A; Lasku R; Kurti A; Klosi, geo historic study, publishing house Ilar, Tirana 2010, pages $13,28,300$ 